\title{
HEMATOLOGICAL AND OXIDATIVE STATUS PARAMETERS IN DOMESTIC DOGS NATURALLY INFESTED BY RHIPICEPHALUS SP.
}

\author{
Rosa Kebbi ${ }^{1}$, Omar Besseboua ${ }^{2}$, Melaaz Belhadj-Kebbi ${ }^{1}$, \\ Lila Hassissen ${ }^{3}$, Abdelhanine Ayad ${ }^{1}$ \\ ${ }^{1}$ Department of Environment Biological Sciences, Faculty of Nature and Life Sciences, \\ University of Bejaia, 06000 Bejaia, Algeria \\ ${ }^{2}$ Department of Agronomic and Biotechnological Sciences, Faculty of Nature and Life \\ Sciences, University Hassiba Benbouali, 02000 Chlef, Algeria \\ ${ }^{3}$ Private Veterinary Practice, Sidi-Ahmed District, 06000, Bejaia, Algeria
}

Received 20 February 2020; Received in revised form 27 May 2020; Accepted 9 June 2020

\begin{abstract}
The present study was aimed to evaluate hematological and oxidative stress parameters in domestic dogs infested naturally $(\mathrm{n}=10)$ by Rhipicephalus sp. to compare with non-infested dogs $(\mathrm{n}=10)$. All blood samples were collected from brachial vein into tubes EDTA for the hematological analysis such as red blood cells (RBCs), white blood cells (WBCs), hemoglobin (HGB) and platelets (PLT). Serum was rapidly separated after centrifugation and stored at $-20^{\circ} \mathrm{C}$ until it was used for malondialdehyde (MDA) and 2,2'-Azinobis-(3-ethylbenzothiazoline)-6-sulfonic acid (ABTS) inhibition measurements. HGB in non-infested dogs was significantly higher than in infested $\operatorname{dogs}(\mathrm{P}<0.05)$. There was no significant difference in $\mathrm{RBCs}$, WBCs and PLT between both groups $(\mathrm{P}>0.05)$. The mean of MDA concentration was high in infested $\operatorname{dogs}(0.92 \pm 0.62 \mathrm{nmol} / \mathrm{ml})$ compared to non-infested dogs $(0.75 \pm 0.25 \mathrm{nmol} / \mathrm{ml})$. On the other hand, the percentage of ABTS inhibition was similar in both groups $(\mathrm{P}=0.71)$. High tick number seems significantly affected WBCs $(\mathrm{P}<0.0001)$ and HGB $(\mathrm{P}<0.001)$ in infested dogs. Concerning oxidative status, there was no significant differences $(\mathrm{P}>0.05)$ between low and high infested dogs, neither in the amount of MDA nor in the ABTS inhibition. In conclusion, infested dogs induced RBCs alterations, which coincided with the oxidative damage, as evidenced by MDA serum levels. Also, there was a relationship between the tick number in infested dogs and the hematological parameters.
\end{abstract}

Key words: Rhipicephalus sp., hematological parameters, oxidative status, dogs

\section{INTRODUCTION}

Ticks (Ixodidae) are arthropods that live as blood-sucking ectoparasites (1). Hard ticks cause major health problems in dogs and transmit an important number of diseases to other animals and to humans as well, such as Babesia, Theileria and Anaplasma spp. (2). They attach to the dog's body and their bites cause irritation, redness, itching,

Corresponding author: Prof. Abdelhanine Ayad, $\mathrm{PhD}$

E-mail address: hanine06@gmail.com

Present address: Department of Environment Biological Sciences,

Faculty of Nature and Life Sciences, University of Bejaia,

Route de Targa Ouzemmour, Bejaia, 06000, Algeria

Phone: +213772 722595

Copyright: (C) 2020 Ayad A. This is an open-access article published under the terms of the Creative Commons Attribution License which permits unrestricted use, distribution, and reproduction in any medium, provided the original author and source are credited.

Competing Interests: The authors have declared that no competing interests exist.

Available Online First: 30 July 2020

Published on: 15 October 2020

https://doi.org/10.2478/macvetrev-2020-0022 auto-traumatic reactions and anaemia (3). A recent study in Algeria (Bejaia province) demonstrates that Rhipicephalus sp. are the most prevalent species in domestic dogs (4). The most damaging impact of tick bites is the release of neurotoxins from tick saliva causing dog paralysis, systemic diseases and hypersensitivity reactions (5). These neurotoxins can interfere with acetylcholine at the neuromuscular junction, resulting in the release of neuromuscular blockage (6). Oxidative stress corresponds to an imbalance between the rate of oxidants production and that of their degradation in favor of the excessive generation of free radicals and other reactive oxygen species (ROS) (7). Several scientific papers reported that the primary or secondary cause of animal diseases are due to an oxidative damage of tissues and cellular components (8). These play an important part in tissue-related pathophysiological mechanisms 
(9). Free radicals are high-reactive substances that are continually produced during metabolic processes. Excess free radicals cause alterations in DNA, enzymes, and membranes, and lead to changes in immune system activity (10). Lipid peroxidation is a mechanism of cell damage used as an indicator of oxidative stress in body fluids of cells and tissues. Lipid peroxides are unstable compounds that give a complex series of reactive carbonyl compounds when they decompose. Polyunsaturated fatty acid peroxides produce a monodialdehyde (MDA) during decomposition (11). Moreover, the mensuration of ABTS (2,2-Azinobis (3-ethylbenzothiazoline)-6-sulphonic acid) levels is one parameter to evaluate oxidative stress status.

Several studies confirmed the occurrence of oxidative stress in animals infected with parasites $(12,13)$. There would be significant changes in the hematology and biochemistry of the hosts suffering from parasitic infestation, depending on the parasite species and the affected body sites (14). These hematological and biochemical alterations can be useful in assessment of infestation severity, animal physiological status, and management practice planning (15). To our best knowledge, there is not a sufficient literature on hematological and oxidative stress values on infested animals by parasites, especially tick-related infestations. We hypothesized that Rhipicephalus sp. would alter specific hematological and oxidative stress indices in infested dogs. Therefore, this present study was aimed to evaluate the hematological and oxidative stress parameters in domestic dogs naturally infested by Rhipicephalus sp. ticks (Ixodidae).

\section{MATERIAL AND METHODS}

\section{Animals and samples}

The study protocol was approved by the Scientific Committee of the Faculty (University of Bejaia). Blood sampling of the dogs was carried out following the rules of well established veterinary practice. The present study was conducted on dogs presented in veterinary clinic situated in Bejaia province $\left(36^{\circ} 43^{\prime} \mathrm{N}, 5^{\circ} 04^{\prime} \mathrm{E}\right)$ for different reasons (care, vaccinations, etc.) from April to July 2016. This study was carried out on two animal groups of various breeds ( $n=20$ with mixed sex and ages). During the study period, infested dogs with Rhipicephalus sp. and healthy dogs were selected randomly from different habitats (home and farmhouse) after a dermatological examination.
The number of collected ticks was recorded for each dog. All ticks were removed manually, retaining the rostral implantation intact. They were stored in labeled plastic containers with $70 \%$ ethanol. Each tick was identified using a stereomicroscope (MOTIC, ST-37C-2LOO), according to the standard morphological identification keys (16).

All blood samples for hematological analysis were collected from the brachial vein and were stored in EDTA tubes. Serum was rapidly separated after centrifugation at $1200 \mathrm{rpm}$ for $20 \mathrm{~min}$ and stored at $-20{ }^{\circ} \mathrm{C}$ until use for oxidative status measurements.

\section{Hematological and oxidative status measurement}

Hematological indices measurement such as red blood cells (RBCs), white blood cells (WBCs), hemoglobin (HGB) and platelets (PLT) was carried out using automatic blood counter (SWELAB alfa, Boule Medical AB, Spanga, Sweden).

\section{Thiobarbituric acid reaction substances} (TBARs) assay

Serum MDA concentration (nmol/ml) was measured according to the method of Sivonova et al. (17), with some modifications. In order to precipitate protein, $1 \mathrm{ml}$ of the serum sample was added to $0.5 \mathrm{ml}$ of trichloroacetic acid (TCA 30\%) and incubated at $0{ }^{\circ} \mathrm{C}$ during $2 \mathrm{~h}$. The mixture was centrifuged $\left(3000 \mathrm{x} \mathrm{g}\right.$ for $10 \mathrm{~min}$ at $\left.4^{\circ} \mathrm{C}\right)$. Following this step, $1 \mathrm{ml}$ of the supernatant was mixed in $0.25 \mathrm{ml}$ of thiobarbituric acid (TBA, $1 \%$ diluted in $0.05 \mathrm{~mol} / 1 \mathrm{NaOH})$ and $0.075 \mathrm{ml}$ of EDTA $(0.1 \mathrm{~mol} / \mathrm{l})$ in a glass tube and placed into a boiling water bath $\left(95{ }^{\circ} \mathrm{C}\right)$ for $15 \mathrm{~min}$, and immediately cooled in an ice bath $\left(0^{\circ} \mathrm{C}\right)$ to stop the chemical reaction. The thiobarbituric acid reactive substances (TBARs) were then quantified using a spectrophotometer (Biotech Engineering Management Co. Ltd. UK VIS-7220G) at a wavelength of $532 \mathrm{~nm}$. The estimated MDA rate $(\mathrm{nmol} / \mathrm{ml})$ was calculated using the formula:

$$
[\mathrm{MDA}]=\frac{\text { sample abs }}{1.56} \times 10 \mathrm{nmol} / \mathrm{ml}
$$

\section{Total antioxidant capacity (TAC) assay}

The total antioxidant capacity was measured with the radical cation decolorization assay (18). This assay is based on the inhibition by antioxidants of the radical cation absorbance of diammonium salt ABTS. In brief, ABTS was dissolved in deionized water to produce a solution of $7 \mathrm{mmol} / \mathrm{l}$ concentration. ABTS+ was generated 
by mixing the ABTS stock solution with $2.45 \mathrm{~mol} / 1$ of potassium persulfate, and the mixture was left in the dark at room temperature for 12-16 $\mathrm{h}$. The ABTS+ solution was dissolved with PBS at $\mathrm{pH} 7.4$ to an absorbance of $0.7( \pm 0.02)$ at $734 \mathrm{~nm}$. After adding $2 \mathrm{ml}$ of ABTS+ diluted to $20 \mu \mathrm{l}$ of sample in PBS, the absorbance was taken exactly $6 \mathrm{~min}$ after the initial mixing. PBS was used in each test as blank. The free radical trapping capacity of the biological sample was expressed as the percentage inhibition of ABTS + . The data obtained were used to determine the ABTS+ inhibition (\%) using the formula:

$$
\% \text { inhibition }=\frac{\text { blank abs-sample abs }}{\text { blank abs }} \times 100
$$

\section{Statistical analysis}

Data were analysed using a mixed model for repeated measurements using Statview Software, Version 4.02 (Abacus concepts Inc., Berkeley, CA,
USA). Statistical analysis was performed using Fisher's test to compare infested and non-infested dogs. The values were expressed as mean $\pm \mathrm{SD}$, and $\mathrm{P}<0.05$ was considered as significant.

\section{RESULTS}

In this study, a total 55 matured hard ticks (41 males and 14 females) were collected and identified from domestic dogs. The microscopic observation revealed of Rhipicephalus sanguineus, Rhipicephalus bursa and Rhipicephalus turanicus based on external morphological characteristics (Fig. 1).

The mean $\pm \mathrm{SE}$ values of hematological parameters of infested dogs by Rhipicephalus sp. and non-infested shown in Table 1. HGB in non-infested dogs were significantly higher than in infested dogs by Rhipicephalus sp. There were no statistically significant differences in RBCs, WBCs and PLT

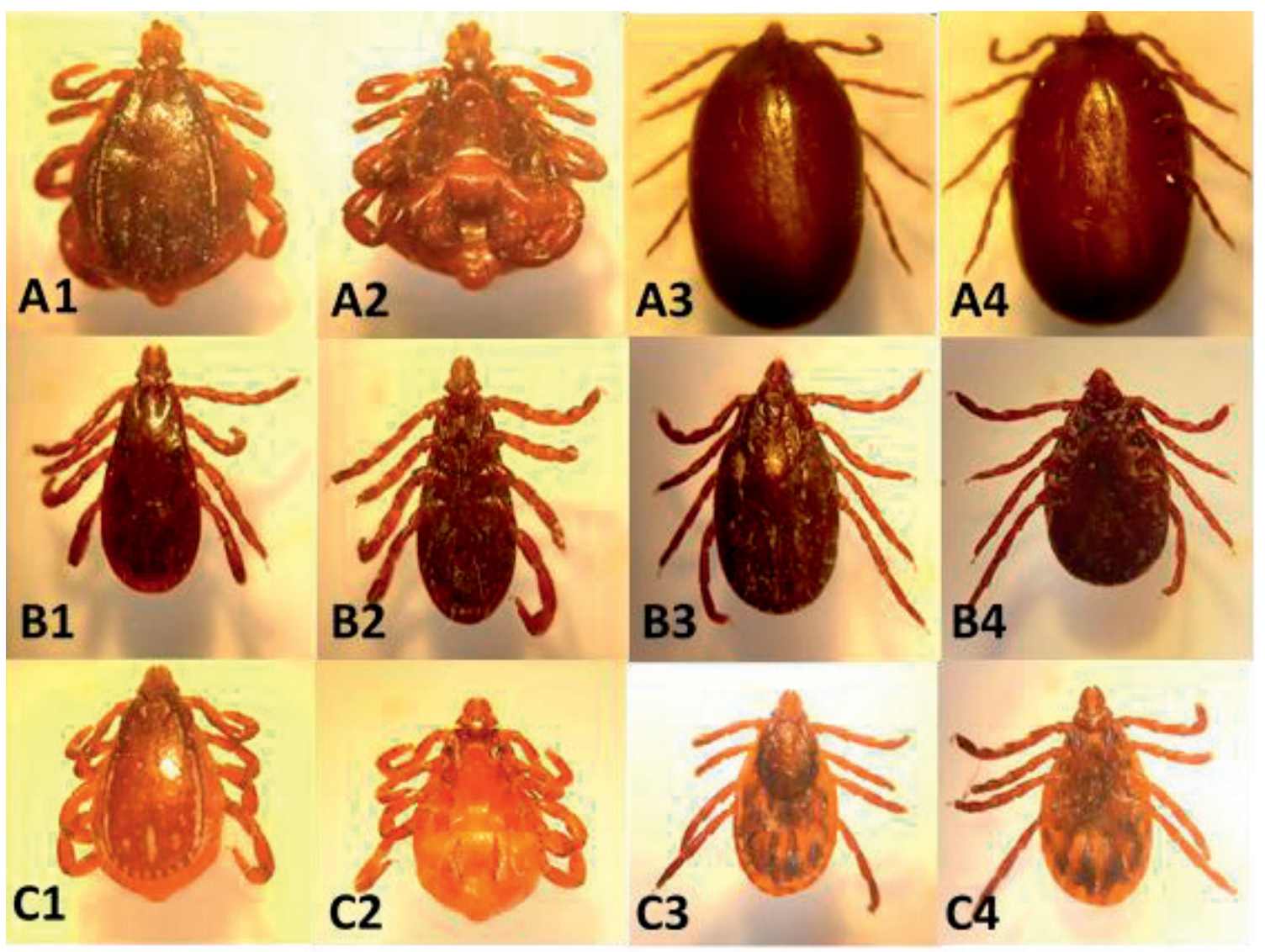

Figure 1. Ticks infestation on dogs. Rhipicephalus turanicus male (A1, A2), Rhipicephalus turanicus female (A3, A4), Rhipicephalus bursa male (B1, B2), Rhipicephalus bursa female (B3, B4), Rhipicephalus sanguineus male (C1, $\mathrm{C} 2)$ and Rhipicephalus sanguineus female $(\mathrm{C} 3, \mathrm{C} 4)$ with dorsal and ventral face, respectively 
Table 1. Values (mean \pm SE) of hematological parameters of non-infested and naturally infested dogs by Rhipicephalus sp.

\begin{tabular}{llll}
\hline Hematological parameters & $\begin{array}{l}\text { Non-Infested } \\
\text { animals }\end{array}$ & $\begin{array}{l}\text { Infested } \\
\text { animals }\end{array}$ & P-values \\
\hline HGB $(\mathbf{g} / \mathbf{d l})$ & $10.68 \pm 1.77$ & $8.22 \pm 2.17$ & $0.01^{*}$ \\
RBCs $\left(\mathbf{1 0}^{\mathbf{6}} / \mathbf{m m}^{\mathbf{3}}\right)$ & $4.86 \pm 0.79$ & $4.52 \pm 1.51$ & 0.58 \\
WBCs $\left(\mathbf{1 0}^{\mathbf{3}} / \mathbf{m m}^{\mathbf{3}}\right)$ & $9.17 \pm 3.83$ & $786.85 \pm 3.92$ & 0.46 \\
PLT $\left(\mathbf{1 0}^{\mathbf{3}} / \mathbf{m m}^{\mathbf{3}}\right)$ & $177.9 \pm 128.47$ & $215.60 \pm 61.74$ & 0.44 \\
\hline
\end{tabular}

* Statistically significant $(\mathrm{P}<0.05)$

between both groups $(\mathrm{P}>0.05)$. The mean values of $\mathrm{RBC}$ and PLT were practically similar in infested and non-infested dogs.

Fig. 2A and 2B illustrate the MDA concentrations and ABTS+ inhibition in infested by Rhipicephalus sp. and non-infested dogs, respectively. The mean of MDA concentration was high in infested dogs by Rhipicephalus sp. $(0.92 \pm 0.62 \mathrm{nmol} / \mathrm{ml})$ compared to non-infested dogs $(0.75 \pm 0.25 \mathrm{nmol} / \mathrm{ml})(\mathrm{P}<0.01)$. On the other hand, the percentage of ABTS+ inhibition was similar in both groups $(\mathrm{P}=0.71)$.
The results of relationships between the tick number in dogs (Low: $n \leq 5$, High: $n>5$ ) and hematological and oxidative status parameters are presented in Table 2. High tick number seems significantly affected WBCs $(\mathrm{P}<0.0001)$ and HGB $(\mathrm{P}<0.001)$ in infested dogs. With regard to $\mathrm{RBCs}$ and PLT, it was not affected by the tick number in infested dogs. Regarding oxidative status, there are no statically significant differences $(\mathrm{P}>0.05)$ between low and high infested dogs neither in the amount of MDA nor in the ABTS+ inhibition.
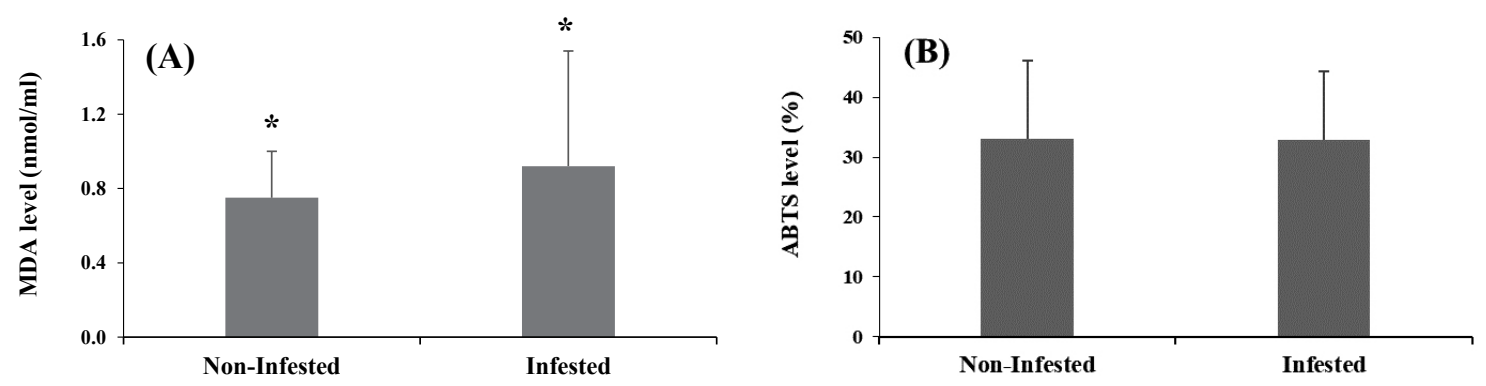

Figure 2. MDA concentrations (A) and total antioxidant capacity (B) in non-infested and naturally infested dogs by Rhipicephalus sp. * Significant difference in value levels between non-infested and infested $\operatorname{dogs}(P<0.05)$

Table 2. Relationships between the tick (Rhipicephalus sp.) number in dogs (Low: $\mathrm{n} \leq 5$, High: $\mathrm{n}>5$ ) and hematological and oxidative status parameters (mean \pm SD)

\begin{tabular}{llll}
\hline & Low level of infestation & High level of infestation & P-values \\
\hline Hematological parameters & & & \\
\hline HGB $(\mathbf{g} / \mathbf{d l})$ & $7.16 \pm 1.12$ & $9.80 \pm 2.31$ & $0.0411^{*}$ \\
RBCs $\left(\mathbf{1 0} / \mathbf{m m}^{3}\right)$ & $4.36 \pm 1.81$ & $4.73 \pm 0.79$ & 0.7169 \\
WBCs $\left(\mathbf{1 0}^{\mathbf{3}} / \mathbf{m m}^{3}\right)$ & $5.20 \pm 1.67$ & $11.85 \pm 2.44$ & $0.0009^{* *}$ \\
PLT $\left(\mathbf{1 0}^{3} / \mathbf{m m}^{3}\right)$ & $212.00 \pm 82.07$ & $221.00 \pm 84.49$ & 0.8707 \\
\hline Oxidative stress markers & & & 0.213 \\
\hline MDA (nmol/ml) & $1.13 \pm 0.11$ & $0.61 \pm 0.10$ & 0.236 \\
ABTS (\%) & $31.25 \pm 3.15$ & $34.65 \pm 2.00$ & \\
\hline
\end{tabular}

*Statistically significant $(\mathrm{P}<0.001)$; **Statistically significant $(\mathrm{P}<0.0001)$ 


\section{DISCUSSION}

Many physiological situations may alter the physiological equilibrium that is maintained mainly by the blood in the body (19). Medical analysis is an important tool that helps veterinary practitioners to successfully diagnose the disease in a fast way and to a better understand their impact on animal health. Modifications in biochemical and hematological values can help in the understanding of the physiological and pathological status of animal (20). Antioxidants are chemicals that inhibit the oxidations of other chemicals. They are involved in preventing cellular damages from oxidative stress and also lower the risk of chronic diseases (21). It is well-documented that the balance between oxidants and antioxidants is essential for maintaining the animal physiology. The present study was conducted in order to assess the hematological and oxidative stress indices in domestic dogs naturally infested by Rhipicephalus sp. ticks.

Anemia is functionally defined as decreased oxygen carrying capacity of blood. This condition is clinically characterized by reduction in the HGB, hematocrit or RBC per unit volume of blood in a normally hydrated animal (22). In the present study, the comparison of some hematological parameters between both groups revealed that WBC and HGB were negatively affected, and were potentially manifested by clinical signs (anemia) as a result of the hematophagous ticks. It is also due to the hemolytic effect the protozoan parasites (Theileria, Babesia) transmitted by ticks. It has been reported that Theileria infection in cattle resulted in anemia associated to significant decreases in RBC, HGB, packed cell volume (PCV), and PLT (23). A similar observation was reported by other researchers, where babesiosis and theileriosis induced significant decrease in RBC, HGB and PCV, resulting in severe anemia $(23,24)$. The results obtained by Lic et al. (25) corroborate our results which showed a significant difference in WBC between dogs with babesiosis $\left(10.5 \times 10^{3} / \mathrm{mm}^{3}\right)$ and control $\left(4.6 \times 10^{3} / \mathrm{mm}^{3}\right)$.

In another investigation Kaur et al. (26), it was indicated that the PLT in tick-infested cattle was significantly higher $(\mathrm{P}<0.01)$ compared to the control.

Recently, Kaur et al. (26) showed that there was a significant reduction in the hematological parameters of cattle following heavy tick infestations. Our finding is in agreement with those reported by Pfäffle et al. (27) which reported that PLT, in the infested population were directly correlated with the tick-infestation level. In addition, Tinoco-Gracia et al. (28) considers that the parasite intensity is severe when the number of ticks on the host exceeds 30 . The results of the present study revealed that the dogs were anemic and dehydrated as compared to non-infested dogs due to high-level of tick infestation. It is important to remember that anemia and inflammatory stimuli influence the release of thrombocytes from the spleen pool or the bone marrow. Moreover, the decreased lymphocytes can be an indication of an inflammatory or an immune response due to pathogen infection (29).

The results of the current research are consistent with preceding scientific report where changes in the antioxidant system have been demonstrated with a variety of parasite infestations in animals (30). This is supported by Singh et al. (31) who demonstrated that significant alteration in oxidant/antioxidant balance may be implicated in pathogenesis of clinical Sarcoptic mite infestation. The results obtained by Ellah et al. (23) and Al-Hosary et al. (13) on the influence of parasitism by Theileria sp. on MDA levels $(\mathrm{P}<0.0001)$ in cattle and sheep have demonstrated correlation of parasitic infestation with occurrence of oxidative stress in the hosts. Similar observations have been reported by Crnogaj et al. (32) which observed a decrease in antioxidant biomarkers (SOD, GPx and catalase) in dogs naturally infected by B. canis canis. Kiral et al. (33) reported that MDA level in dogs infested by $H$. canis was higher than the controls. Also, another investigation showed that there was a significantly different in serum MDA levels $(\mathrm{P}<0.0005)$ between the healthy control group $(8.13 \pm 1.78 \mu \mathrm{mol} / \mathrm{l})$ and $\operatorname{dogs}$ with diagnosed babesiosis $(36.90 \pm 13.95 \mu \mathrm{mol} / \mathrm{l})$ (34). In the present study, the level of serum lipid peroxidation product (MDA) indicated the occurrence of oxidative stress in infected dogs, which may be considered as an indication of cell injury caused by Rhipicephalus sp. This may be related to an incapacity of the antioxidant mechanism to evacuate reactive oxygen species. It is known that total antioxidant status evaluates the general antioxidant activity of the organism (35). Therefore, it is noted that the presence of parasites affects the detoxifying systems by altering their concentrations or syntesis (36). In the current investigation, the level increased of TAC in dogs infected by Rhipicephalus sp. may probably be ascribed to the production of antioxidant enzymes as free radical scavengers during the oxidative process. It has also been demonstrated by that the presence of parasites could modify host defense 
systems. The same authors recorded an increased activity of antioxidant enzymes in Cyprinus carpio infected with cestode Ptychobothrium sp. (37). Recently, Al-Hosary et al. (13) reported a significant increase in serum TAC in ewes infected with ticks. These results agree with those reported earlier in sheep (38), and dogs infested by babesiosis (32). Furthermore, Ciftci et al. (39) observed that TAC levels decreased in Babesia vogeli infested dogs, but these variations were not found as statistically significant $(\mathrm{P}>0.05)$. However, Crnogaj et al. (34) obtained a TAC values which were significantly lower in dogs infested by Babesia canis canis compared to controls. This difference could be justified by the limited number of samples collected in the current investigation and can also be attributed to other physiological factors in animals such as gestation, lactation, and age, which is coupled with the releasing of free radicals in the body and constitutes a further source of oxidative stress (13).

\section{CONCLUSION}

Based on the results of the present study, it was concluded that infestation by Rhipicephalus sp. in infested dogs induces hematological indices alterations which coincides with the oxidative damage, as evidenced by changes in MDA serum levels. Also, there was a relationship between the tick number in infested dogs and the analyzed hematological parameters. Future studies with higher sample size should aim in determining the risk factors which would contribute to more effective disease control strategies.

\section{CONFLICT OF INTEREST STATEMENT}

The authors declare that they have no potential conflict of interest.

\section{ACKNOWLEDGEMENTS}

The authors gratefully acknowledge the Associated Laboratory in Marine Ecosystems and Aquaculture, University of Bejaia, Algeria that support this study.

\section{AUTHORS' CONTRIBUTIONS}

RK carried out the experimental work and wrote the manuscript. OB and MBK reviewed the manuscript. LH contributed in the sampling. AA designed, supervised the experimental study and reviewed the manuscript. All authors read and approved the final manuscript.

\section{REFERENCES}

1. Laamri, M., El Kharrim, K., Boukbal, M., Belghyti, D., Mrifag, R. (2012). Population dynamics of parasitic ticks from cattle in the Gharb region in Morocco. Rev Elev Med Vet Pays Trop. 65(3-4): 57. https://doi.org/10.19182/remvt.10123

2. Gray, J., Dantas-Torres, F., Estrada-Pena, A., Levin, M. (2013). Systematics and ecology of the brown dog tick, Rhipicephalus sanguineus. Ticks. Tick-Borne Dis. 4(3): 171-180.

https://doi.org/10.1016/j.ttbdis.2012.12.003 PMid:23415851

3. Taylor, M., Mediannikov, O., Raoult, D., Greub, G. (2012). Endosymbiotic bacteria associated with nematodes, ticks and amoebae. FEMS Immunol Med Microbiol. 64(1): 21-31.

4. Kebbi, R., Nait-Mouloud, M., Hassissen, L., Ayad, A. (2019). Seasonal activity of ticks infesting domestic dogs in Bejaia province, Northern Algeria. Onderstepoort J Vet Res. 86(1): e1-e6. https://doi.org/10.4102/ojvr.v86i1.1755 PMid:31714138 PMCid:PMC6852545

5. Smith, F.D., Wall, L.E.R. (2013). Prevalence of Babesia and Anaplasma in ticks infesting dogs in Great Britain. Vet parasitol. 198(1-2): 18-23. https://doi.org/10.1016/j.vetpar.2013.08.026 PMid:24055106

6. Edlow, J.A., McGillicuddy, D.C. (2008). Tick paralysis. Inf Dis Clin North Am. 22(3): 397-413. https://doi.org/10.1016/j.idc.2008.03.005 PMid:18755381

7. Sorg, O. (2004). Oxidative stress: a theoretical model or a biological reality? C R Biol. 327(7): 649-662. https://doi.org/10.1016/j.crvi.2004.05.007 PMid:15344815

8. Sordillo, L.M., Aitken, S.L. (2009). Impact of oxidative stress on the health and immune function of dairy cattle. Vet Immunol Immunopathol. 128(1-3): 104-109.

https://doi.org/10.1016/j.vetimm.2008.10.305

PMid:19027173

9. Codoñer-Franch, P., Valls-Bellés, V., Arilla-Codoñer, A., Alonso-Iglesias, E. (2011). Oxidant mechanisms in childhood obesity: the link between inflammation and oxidative stress. Transl Res. 158(6): 369-384. https://doi.org/10.1016/j.trs1.2011.08.004 PMid:22061044 
10. Abd Ellah, M.R. (2010). Involvement of free radicals in animal diseases. Comp Clin Pathol. 19, 615-619. https://doi.org/10.1007/s00580-010-1016-3

11. Repetto, M., Semprine, J., Boveris, A. (2012). Lipid peroxidation: chemical mechanism, biological implications and analytical determination. In: A. Catala (Eds.) (pp. 3-30). Rijeka: InTech. https://doi.org/10.5772/45943

12. Samadieh, H., Mohammadi, G.R., Maleki, M., Borji, H., Azizzadeh, M., Heidarpour, M. (2017). Relationships between oxidative stress, liver, and erythrocyte injury, trace elements and parasite burden in sheep naturally infected with Dicrocoelium dendriticum. Iran J Parasitol. 12(1): 46-55.

13. Al-Hosary, A.A.T., Abd Ellah, M.R., Salah El-Din Ahmed, L. (2018). Evaluation of oxidative stress in sheep infested with ticks and concurrent diagnosis of Theileriosis. Asian J Anim Vet Adv. 13(3): 263-268.

https://doi.org/10.3923/ajava.2018.263.268

14. Mir, M.R., Pampori, Z.A., Iqbal, S., Bhat, J.I., Pal, M.A., Kirmani, M.A. (2008). Hemato-biochemical indices of crossbred cows during different stages of pregnancy. Int J Dairy Sci. 3(3): 154-159.

https://doi.org/10.3923/ijds.2008.154.159

15. Sarma, K., Mondal, D., Saravanan, M., Mahendran, K. (2015). Evaluation of haemato-biochemical and oxidative indices in naturally infected concomitant tick-borne intracellular diseases in dogs. Asian Pac J Trop Dis. 5(1): 60-66. https://doi.org/10.1016/S2222-1808(14)60627-7

16. Walker, A.R., Bouattour, A., Camicas, J.L., Estrada-Peña,A.,Horak,I.G.,Latif,A.A.,Pegram,R.G., Preston, P.M. (2014). Ticks of domestic animals in Africa: A guide to identification of species. University of Edinburgh, Edinburgh, Scotland UK: Bioscience Reports.

17. Sivoňová, M., Waczulikova, I., Kilanczyk, E., Hrnčiarová, M., Bryszewska, M., Klajnert, B., Duračková, Z. (2004). The effect of Pycnogenol on the erythrocyte membrane fluidity. Gen Physiol Biophys. 23(1): 39-51.

18. Re, R., Pellegrini, N., Proteggente, A., Pannala, A., Yang, M., Rice-Evans, C. (1999). Antioxidant activity applying an improved ABTS radical cation decolorization assay. Free Radic Biol Med. 26(9-10): 1231-1237.

https://doi.org/10.1016/S0891-5849(98)00315-3

19. Geneser, F. (1986). Textbook of histology. 1st Ed. Munksgaard Copenhagen, Denmark: Wiley-Blackwell.
20. Ahmad, I., Gohar, A., Ahmad, N., Ahmed, M. (2003). Haematological profile in cyclic, non-cyclic and endometritic cross-bred cattle. Int J Agr Biol. 5(3): 332-334.

21. Lu, Y., Zhang, Y., Shan, H., Pan, Z., Li, X., Li, B., Song, W. (2009). MicroRNA-1 downregulation by propranolol in a rat model of myocardial infarction: a new mechanism for ischaemic cardioprotection. Cardiovasc Res. 84(3): 434-441.

https://doi.org/10.1093/cvr/cvp232

PMid:19581315

22. Singh, J., Gupta, S.K., Singh, R., Hussain, S.A. (2014). Etiology and haemato-biochemical alterations in cattle of Jammu suffering from anaemia. Vet World. 7(2): 49-51.

https://doi.org/10.14202/vetworld.2014.49-51

23. Ellah, M.R.A., Al-Hosary, A.A.T. (2011). Cattle theileriosis: effect on serum constituents, erythrocytes and platelets pictures. Proceedings of the XVth International Congress of the International Society for Animal Hygiene, Vienna, Austria. Tribun EU 2. pp. 909-912.

24. Al-Hosary, A.A.T., Elsayed, H.K., Ahmed, L.S. (2015). Oxidative stress and hematological profile in Theileria annulata clinically infected cattle before and after treatment. Assiut Vet Med J. 61, 144.

25. Lic, D.P., Zvorc, Z., Kucer, N. (2005). Number of platelets and mean platelet volume in the dog's babesiosis. Rev Med Vet. 156(2): 95-98.

26. Kaur, D., Jaiswal, K., Mishra, S. (2017). Effect of tick infestation on haematological parameters of calves. J Entomol. 5(4): 107-111.

27. Pfäffle, M., Petney, T., Elgas, M., Skuballa, J., Taraschewski, H. (2009). Tick-induced blood loss leads to regenerative anaemia in the European hedgehog (Erinaceus europaeus). Parasitol. 136(4): 443-452.

https://doi.org/10.1017/S0031182009005514 PMid:19216826

28. Tinoco-Gracia, L., Quiroz-Romero, H., Quintero-Martínez, M.T., Rentería-Evangelista, T.B., González-Medina, Y., Barreras-Serrano, A., Horni-Oshina, S., Moro, M.H., Vinasco, J. (2009). Prevalence of Rhipicephalus sanguineus ticks on dogs in a region on the Mexico-USA border. Vet Rec. 164(2): 59-61.

https://doi.org/10.1136/vr.164.2.59

PMid:19136688

29. Thomas, L. (2007). Laboratory and diagnosis, 7th Ed. Frankfurt: TH-Books. [in German] 
30. Dimri, U., Sharma, M.C., Yamdagni, A., Ranjan, R., Zama, M.M.S. (2010). Psoroptic mange infestation increases oxidative stress and decreases antioxidant status in sheep. Vet Parasitol. 168(3-4): 318-322. https://doi.org/10.1016/j.vetpar.2009.11.013 PMid:20045257

31. Singh, S.K., Dimri, U., Sharma, M.C., Swarup, D., Sharma, B. (2011). Determination of oxidative status and apoptosis in peripheral blood of dogs with sarcoptic mange. Vet Parasitol. 178(3-4): 330-338. https://doi.org/10.1016/j.vetpar.2011.01.036 PMid:21324594

32. Crnogaj, M., Cerón, J.J., Šmit, I., Kiš, I., Gotić, J., Brkljačić, M., Mrljak, V. (2017). Relation of antioxidant status at admission and disease severity and outcome in dogs naturally infected with Babesia canis canis. BMC Vet Res. 13(1): 114.

https://doi.org/10.1186/s12917-017-1020-9

PMid:28438201 PMCid:PMC5402640

33. Kiral,F., Karagenc, T.,Pasa, S., Yenisey,C., Seyrek, K. (2005). Dogs with Hepatozoon canis respond to the oxidative stress by increased production of glutathione and nitric oxide. Vet Parasitol. 131(1-2): 15-21.

https://doi.org/10.1016/j.vetpar.2005.04.017

PMid:15936891

34. Crnogaj, M., Petlevski, R., Mrljak, V., Kis, I., Torti, M., Kucer, N, Stokovic, I. (2010). Malondialdehyde levels in serum of dogs infected with Babesia canis. Vet Med. 55(4): 163-171. https://doi.org/10.17221/77/2010-VETMED
35. Aytekin, I., Onmaz, A.C., Ulucan, A., Alp, H. (2011). Effects of accidental ammonium Sulphate poisoning on antioxidant/oxidant status in lambs. Rev Med Vet. 162, 346-51.

36. Baudrimont, M., De Montaudouin, X. (2007). Evidence of an altered protective effect of metallothioneins after cadmium exposure in the digenean parasite-infected cockle (Cerastoderma edule). Parasitol. 134(2): 237-245. https://doi.org/10.1017/S0031182006001375 PMid:17032474

37. Dautremepuits, C., Betoulle, S., Vernet, G. (2003). Stimulation of antioxidant enzymes levels in carp (Cyprinus carpio L.) infected by Ptychobothrium sp. (Cestoda). Fish Shellfish Immun. 15(5): 467-471. https://doi.org/10.1016/S1050-4648(03)00007-X

38. Esmaeilnejad, B., Tavassoli, M., Asri-Rezaei, S., Dalir-Naghadeh, B., Malekinejad, H., Jalilzadeh-Amin, G., Hajipour, N. (2014). Evaluation of antioxidant status, oxidative stress and serum trace mineral levels associated with Babesia ovis parasitemia in sheep. Vet Parasitol. 205(1-2): 38-45.

https://doi.org/10.1016/j.vetpar.2014.07.005 PMid:25086493

39. Ciftci, G., Ural K., Aysul, N., Cenesiz, S., Guzel, M., Pekmezci, D., Sogut, MÜ. (2014). Investigation of the 8-hydroxy-2'-deoxyguanosine, total antioxidant and nitric oxide levels of serum in dogs infected with Babesia vogeli. Vet Parasitol. 204(3-4): 388-391. https://doi.org/10.1016/j.vetpar.2014.05.002 PMid:24882747 